\title{
Physiological responses of tagasaste to a progressive drought in its native environment on the Canary Islands
}

\author{
A.M. González-Rodríguez*, A. Martín-Olivera, D. Morales, M.S. Jiménez \\ Departamento de Biología Vegetal, Facultad de Farmacia, Universidad de La Laguna, E-38207 La Laguna, Tenerife, Spain
}

Accepted 26 March 2004

\begin{abstract}
Diurnal courses of gas exchange, chlorophyll fluorescence, shoot water potential $(\Psi)$ and leaf relative water content $\left(\mathrm{RWC}_{\text {leaf }}\right)$ were recorded in Chamaecytisus proliferus (L. fil.) Link ssp. proliferus var. palmensis (Christ) (tagasaste) growing in natural conditions in the North-West slope of Tenerife, Canary Islands. During the studied period (April-July 2000), the soil relative water content $\left(\mathrm{RWC}_{\text {soil }}\right)$ progressively decreased, while the air vapour pressure deficit increased. As a consequence a decrease in $\Psi$ and $\mathrm{RWC}_{\text {leaf }}$ took place as well as a decrease in stomatal conductance $\left(g_{\mathrm{s}}\right)$ and $\mathrm{CO}_{2}$ assimilation rate $(A)$. These characteristics, typical of an anisohydric plant, allowed this species to endure a mild drought.

Photochemical efficiency of PSII ( $\left.\phi_{\text {PSII }}\right)$ followed the inverse pattern to that observed for the photosynthetic photon flux density (PPFD), decreasing at midday and recovering during the late afternoon. This recovering at the end of each day, and the constant values of the maximum quantum yield of PSII photochemistry $\left(F_{\mathrm{v}} / F_{\mathrm{m}}\right)$ during the studied period, indicate that there was no permanent damage to the photosynthetic apparatus due to mild water stress.
\end{abstract}

(c) 2004 Elsevier B.V. All rights reserved.

Keywords: Anisohydric plants; $\mathrm{CO}_{2}$ assimilation rate; Mediterranean species; Stomatal conductance; Water use efficiency

\section{Introduction}

Mediterranean climates can be considered as a transition between dry tropical and temperate climates. They are characterised by a distinctive annual climatic sequence in which a hot, dry summer alternates with a cool to cold humid period lasting 5-10 months from autumn to spring. There are, however, different opinions about the ranges of annual amounts of rainfall and the extent of summer drought characterising these climates (Daget, 1977).

\footnotetext{
* Corresponding author. Fax: +34-922-318447.

E-mail address: aglerod@ull.es (A.M. González-Rodríguez).
}

The effect of drought on leaf gas exchange in Mediterranean Basin plants has been reviewed by Tenhunen et al. (1987) and Pereira and Chaves (1993). These studies show that drought not only affects the rate of gas exchange, but also results in diurnal changes in activity. Thus, the impact of stress on plants growing under Mediterranean field conditions should be assessed by examining the development of the diurnal variations on leaf gas exchange (Mäkelä et al., 1996; Munné-Bosch et al., 1999). Whereas these ecophysiological parameters are relatively broadly studied under eu-Mediterranean conditions (e.g. Tenhunen et al., 1987; Faria et al., 1998; Gratani and Ghia, 2002), information on plant per- 
formance under humid Mediterranean conditions are scarce.

Tagasaste, formerly also called "tree lucerne" (Chamaecytisus proliferus (L. fil.) Link ssp. proliferus var. palmensis (Christ)), is an endemic fodder tree-shrub from the Canary Islands which has achieved importance in agriculture around the world, particularly in parts of Australia and New Zealand (Francisco-Ortega et al., 1991, 1993). Most studies about this species concentrated on its biomass yield and quality (Arredondo et al., 1998; Assefa, 1998), nutritive value and palatability (Borens and Poppi, 1990; Tolera et al., 1997). Little is known about its physiological responses under natural environmental conditions. Recent studies have been carried out on the water use efficiency and water balance of tagasaste in south-western Australia (Lefroy et al., 2001a,b). However, nothing is known about photosynthetic characteristics and response to drought in its natural habitat.

In the Canary Islands, tagasaste is mainly present from $300 / 400$ to $1300 / 1400 \mathrm{~m}$ above sea level, in gaps and boundary zones of forests in N and NE slopes of the islands (Pérez de Paz et al., 1986) in a humid Mediterranean climate. Because of their ability to symbiotically fix nitrogen, legumes can grow in low quality soils (Van Andel et al., 1993) and have been used for re-vegetation of abandoned, altered or drought affected fields. Tagasaste might also be a suitable candidate for such purposes. The aim of this study is to know the response of tagasaste in its native environment to the natural drought from spring to summer by examining the water status of its shoots and the seasonal development of the diurnal variations in leaf gas exchange and photochemical efficiency of the PSII photochemistry.

\section{Materials and methods}

\subsection{Plant material and experimental site}

The study was conducted with adult plants (more than 10 years old) of Chamaecytisus proliferus subsp. proliferus var. palmensis (tagasaste) from April to July of 2000 in Tenerife, Canary Islands. The plant is an evergreen shrub, which mainly produces new shoots in spring and autumn, but new ones can be seen throughout the year. Measurements were done in similar young shoots. The experimental site is located at an altitude of $950 \mathrm{~m}$, facing $\mathrm{N}$ and has a humid Mediterranean climate with a mean annual temperature between 10 and $13{ }^{\circ} \mathrm{C}$ and a mean annual precipitation of $570 \mathrm{~mm}$.

\subsection{Plant and soil water status}

Shoot water potential $(\Psi)$ of apical non-woody shoots $(N=9)$ was measured three times a day (early morning, midday and late afternoon) using a pressure chamber (PMS Instruments Co., Corvallis, OR, USA).

Relative water content of fully developed young leaves $\left(\mathrm{RWC}_{\text {leaf }}\right)$ was calculated from the same shoots $(N=9)$, as RWC $(\%)=(\mathrm{FW}-\mathrm{DW}) /(\mathrm{SFW}-\mathrm{DW})$ $\times 100$, where FW is fresh weight, DW is dry weight and SFW is saturated fresh weight of the leaves after re-hydrating samples for $24 \mathrm{~h}$ (Turner, 1981).

At sunset, soil samples were taken in steel cylinders (diameter: $3.5 \mathrm{~cm}$ and length: $14 \mathrm{~cm}$ ) and $\mathrm{RWC}_{\text {soil }}$ was calculated in the same way as $\mathrm{RWC}_{\text {leaf }}$.

\subsection{Gas exchange characteristics}

$\mathrm{CO}_{2}$ assimilation rate $(A)$, internal $\mathrm{CO}_{2}$ concentration $\left(C_{\mathrm{i}}\right)$, stomatal conductance $\left(g_{\mathrm{s}}\right)$ and transpiration rate $(E)$ were measured on attached apical non-woody shoots with a portable Infrared Gas Analyser (LCA2, Analytical Development Co. Ltd., Hoddesdon, Herts, UK) every hour from the early morning to the evening. Gas exchange rates were calculated using equations developed by von Caemmerer and Farquhar (1981).

\subsection{Chlorophyll fluorescence}

Components of chlorophyll fluorescence were quantified in situ in the field with a portable modulated fluorometer (Mini-PAM, Walz, Effeltrich, Germany). The instrument was equipped with a leaf-clip holder (2030-B; Walz) and a microquantum sensor for monitoring photosynthetic photon flux density (PPFD) and a thermocouple to measure temperature at the lower leaf surface (Bilger et al., 1995). The fiberoptics axis forms a $60^{\circ}$ angle with the leaf plane, avoiding shading of the sample when external actinic illumination is applied. After clamping the leaf-clip holder onto the leaf, the actual fluorescence $(F)$ was monitored to ascertain 
that it was stable (weak measuring beam). Maximum fluorescence yield $\left(\mathrm{F}_{\mathrm{m}}^{\prime}\right)$ was measured during a $0.8-\mathrm{s}$ saturating flash at $6000 \mu \mathrm{mol} \mathrm{m} \mathrm{m}^{-2} \mathrm{~s}^{-1}$ and exposure to natural illumination. The fraction of absorbed light utilised in electron transport is given by the PSII photochemical efficiency or yield parameter, $\phi_{\mathrm{PSII}}=$ $\Delta F / F^{\prime}{ }_{\mathrm{m}}$, where $\Delta F=F^{\prime}{ }_{\mathrm{m}}-F$ (Genty et al., 1989).

Measurements were made every hour in single attached leaves $(N=9)$. Values of initial $\left(F_{0}\right)$, maximal $\left(F_{\mathrm{m}}\right)$ and the variable to maximum ratio $\left(F_{\mathrm{v}} / F_{\mathrm{m}}\right)$ in dark-adapted leaves, were determined in the laboratory for the same leaves characterized in the field. Leaves were maintained in petri dishes on moist paper in the laboratory at room temperature and darkness for $24 \mathrm{~h}$. Non-photochemical quenching (NPQ) described by $\left(F_{\mathrm{m}}-F_{\mathrm{m}}^{\prime}\right) / F_{\mathrm{m}}^{\prime}$ was determined from in situ field measurements and from pre-illumination measurements with detached and water-saturated leaves in the laboratory. All values of fluorescence were corrected for changes in measuring beam irradiance induced by temperature changes of the Mini-Pam. The correction was calculated according to Demmig-Adams and Adams (1996) by monitoring the fluorescence signal of a standard provided with the instrument.

In addition to chlorophyll fluorescence measurements mentioned above, maximum efficiency of PSII photochemistry $\left(F_{\mathrm{v}} / F_{\mathrm{m}}\right)$ was determined in situ in the field in single attached leaves $(N=9)$ by a time-resolving portable fluorometer (Plant Efficiency Analyser, PEA, Hansatech, UK) after 30 min of dark adaptation using specially designed clips attached to the leaves. Measurements were made throughout the day at $2 \mathrm{~h}$ intervals.

\subsection{Pigments composition}

Photosynthetic (Chlorophyll $a, b$ and carotenoid) pigments from leaves $(N=9)$ of apical non-woody shoots were measured spectrophotometrically in $80 \%$ acetone (v/v) extracts using the equations described by Lichtenthaler (1987).

\subsection{Statistical analysis}

Statistical differences between time of day and measurement days were analysed by ANOVA using SPSS (version 10, Chicago, IL, USA) and were considered significant when $P<0.05$.

\section{Results}

\subsection{Plant and soil water status}

$\mathrm{RWC}_{\text {soil }}$ in the studied period decreased from values of $55 \%$ to $18 \%$ between 25 April and 31 July, showing a strong decrease between 25 April and 31 May (Fig. 1). The shoot water potential $\Psi$ showed significant differences between the measured days as well as with respect to the time of day. $\Psi$ decreased during the morning, as the water demand increased, to recover again during the late afternoon with higher values than in the early morning, except on the last day of measurements when the drought was more pronounced ( $\left.\Psi_{\text {late-afternoon }} 1.01 \mathrm{MPa}\right)$. Drought caused a decrease in $\Psi_{\text {midday }}$ from approx. $-0.7 \mathrm{MPa}$ on 25 April to $-2.0 \mathrm{MPa}$ on 31 July (Fig. 2). $\mathrm{RWC}_{\text {leaf }}$ also showed significant differences during the period under study, decreasing approx. $10 \%$ between the first and last day of the period of measurements; nevertheless, no significant differences between values of 1 day were found (Fig. 2).

\subsection{Gas exchange}

Fig. 3 shows diurnal variations in weather conditions (photosynthetic photon flux density, PPFD; leaf temperature, $T_{\text {leaf }}$ and air vapour pressure deficit, VPD) on four cloudless days during the study period. From April to July, it became progressively hotter and drier. At the beginning of the measurement period (25 April), the lowest maximum mean values of VPD and $T_{\text {leaf }}\left(0.58 \mathrm{kPa}\right.$ and $26^{\circ} \mathrm{C}$, respectively $)$ were

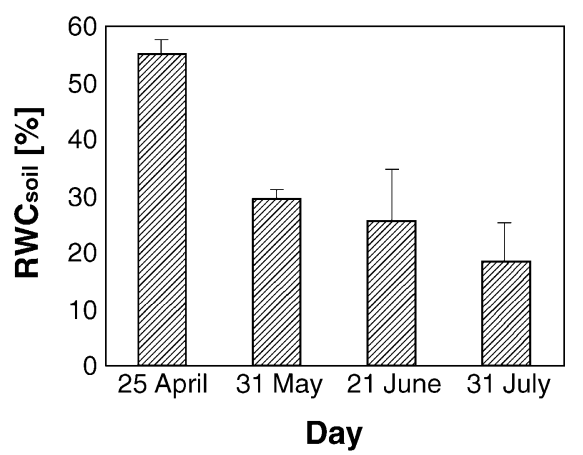

Fig. 1. Relative water content of the soil $\left(\mathrm{RWC}_{\text {soil }}\right.$, vol.\%) during the studied period. 


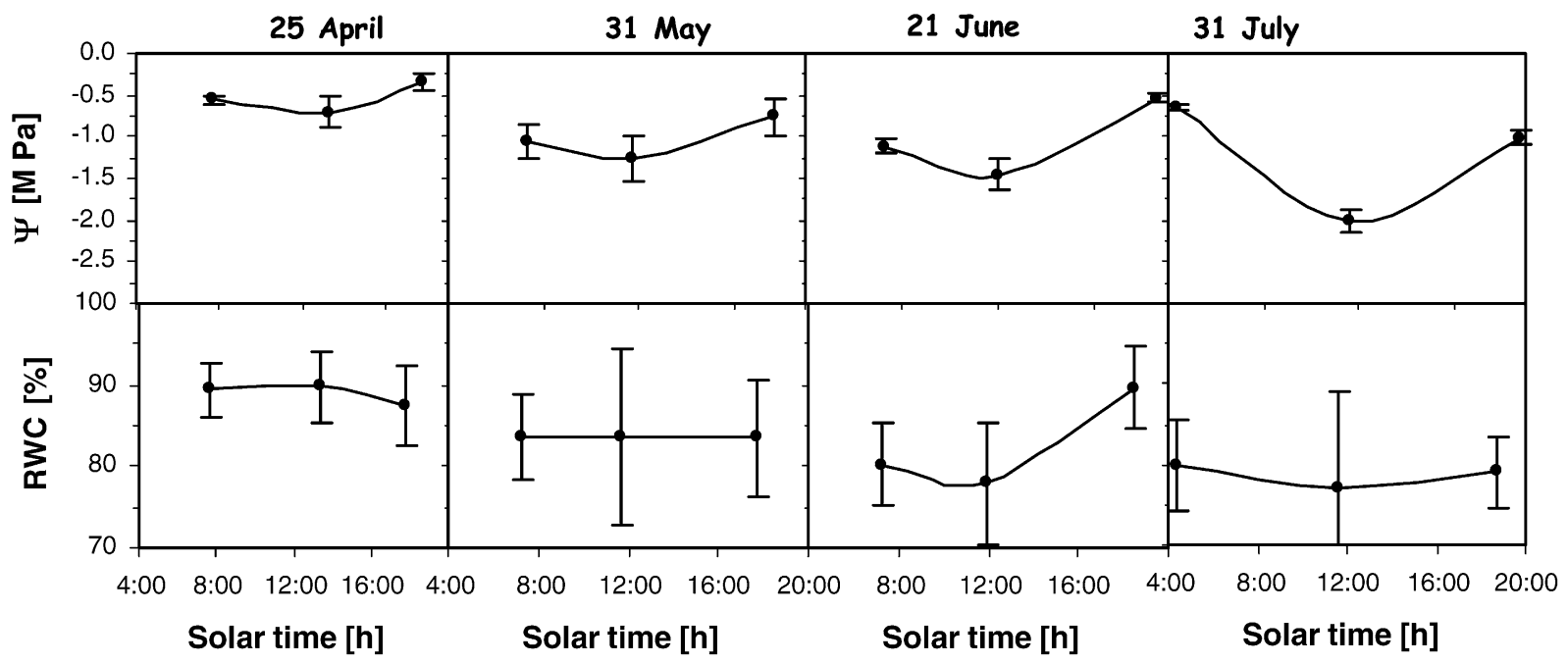

Fig. 2. Diurnal time courses of shoot water potential $(\Psi)$ and relative leaf water content (RWC) of Chamaecytisus proliferus subsp. proliferus var. palmensis (tagasaste) from April to July under field conditions. Each value is a mean \pm S.D., $n=9$.

registered; values of $5 \mathrm{kPa}$ and $40{ }^{\circ} \mathrm{C}$ were reached towards the end.

$A$ and $g_{\mathrm{s}}$ decreased from about $8.5 \mu \mathrm{mol} \mathrm{m}{ }^{-2} \mathrm{~s}^{-1}$ and $163 \mathrm{mmol} \mathrm{m}^{-2} \mathrm{~s}^{-1}$, respectively, in April to a significant minimum of $5 \mu \mathrm{mol} \mathrm{m}^{-2} \mathrm{~s}^{-1}$ and $89 \mathrm{mmol} \mathrm{m}^{-2} \mathrm{~s}^{-1}$ in July. $C_{\mathrm{i}}$ values were high in all studied days (minimum mean values $c$ $\left.325 \mu \mathrm{mol} \mathrm{mol}^{-1}\right)$ and $C_{\mathrm{i}} / C_{\mathrm{a}}$ ratio was always above to 0.95 (Fig. 4).

Instantaneous WUE showed a significant decrease during the experiment, decreasing from 3 to $1.5 \mu \mathrm{mol} \mathrm{mmol}^{-1} . \mathrm{A} / \mathrm{g}_{\mathrm{s}}$ values did not show significant differences with a mean value of $55 \mu \mathrm{mol} \mathrm{mol}^{-1}$ (Fig. 4).

\subsection{Chlorophyll fluorescence}

During the morning, $\phi_{\text {PSII }}$ decreased with changes in PPFD to increase again during the afternoon, reaching a maximum in late afternoon. A maximum reduction of $\phi_{\text {PSII }}$ was obtained at midday, with values around $60 \%$ on July 31 (Fig. 5). Midday $\phi_{\text {PSII }}$ did not show significant differences during the drought period. NPQ paralleled the diurnal pattern of PPFD. Maximum midday NPQ values of 2.4 were reached on July 31 (Fig. 5).

The ratio $F_{\mathrm{v}} / F_{\mathrm{m}}$ remained at similar levels during most hours of the day, reaching minimum values of $c 0.76$ at midday, and they did not show

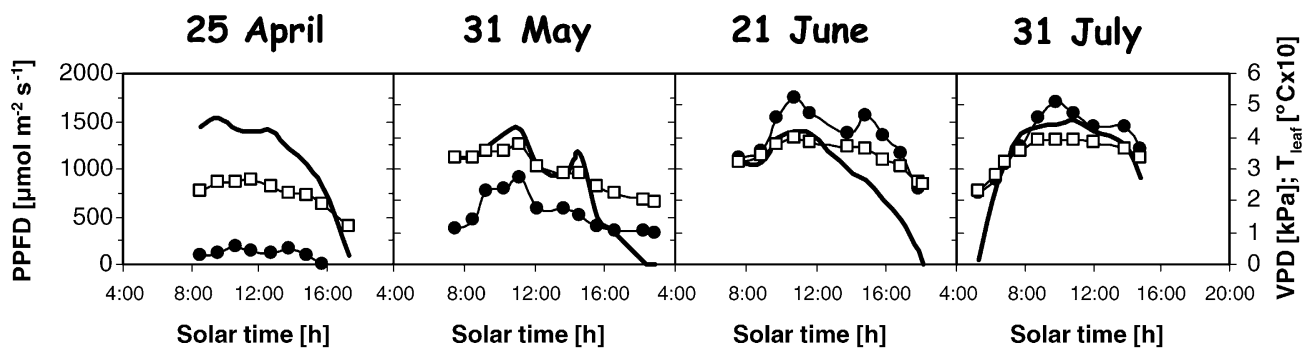

Fig. 3. Diurnal time courses of photosynthetic photon flux density (PPFD; solid line) at leaf surface, leaf temperature ( $T_{\text {leaf }}$; white square) and air vapour pressure deficit (VPD; black circle) on 25 April, 31 May, 21 June and 31 July. Each point represents the mean of six measurements. 

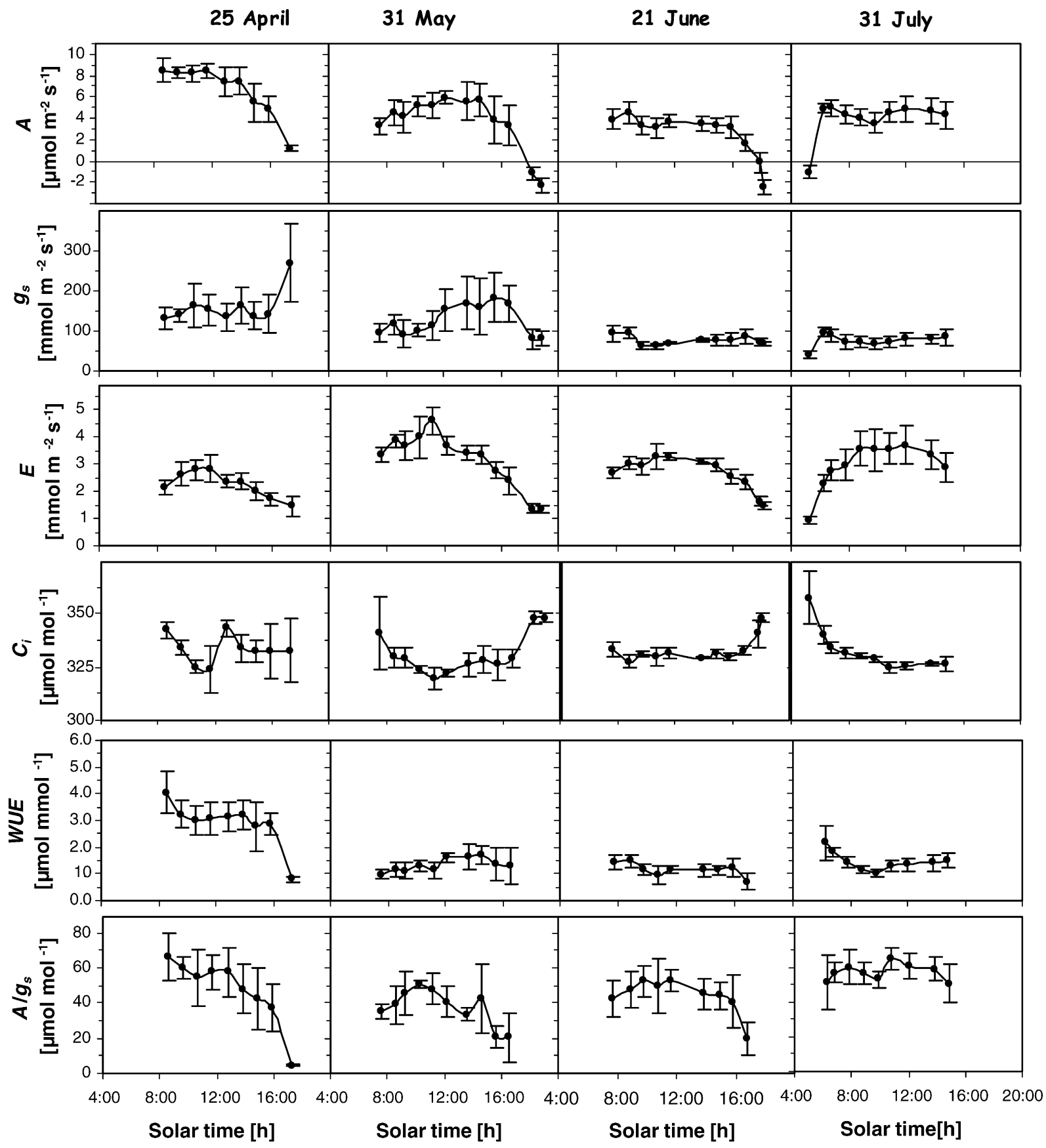

Fig. 4. Diurnal time courses of $\mathrm{CO}_{2}$ assimilation rate $(A)$, transpiration $(E)$, stomatal conductance $\left(g_{\mathrm{s}}\right)$, leaf internal $\mathrm{CO}_{2}$ concentration $\left(C_{\mathrm{i}}\right)$, instantaneous water use efficiency (WUE $=A / E$ ) and intrinsic water use efficiency $\left(A / g_{\mathrm{s}}\right)$ of Chamaecytisus proliferus subsp. proliferus var. palmensis measured in leaves on 25 April, 31 May, 21 June and 31 July. Each point represents the mean of six measurements with their standard deviations. 


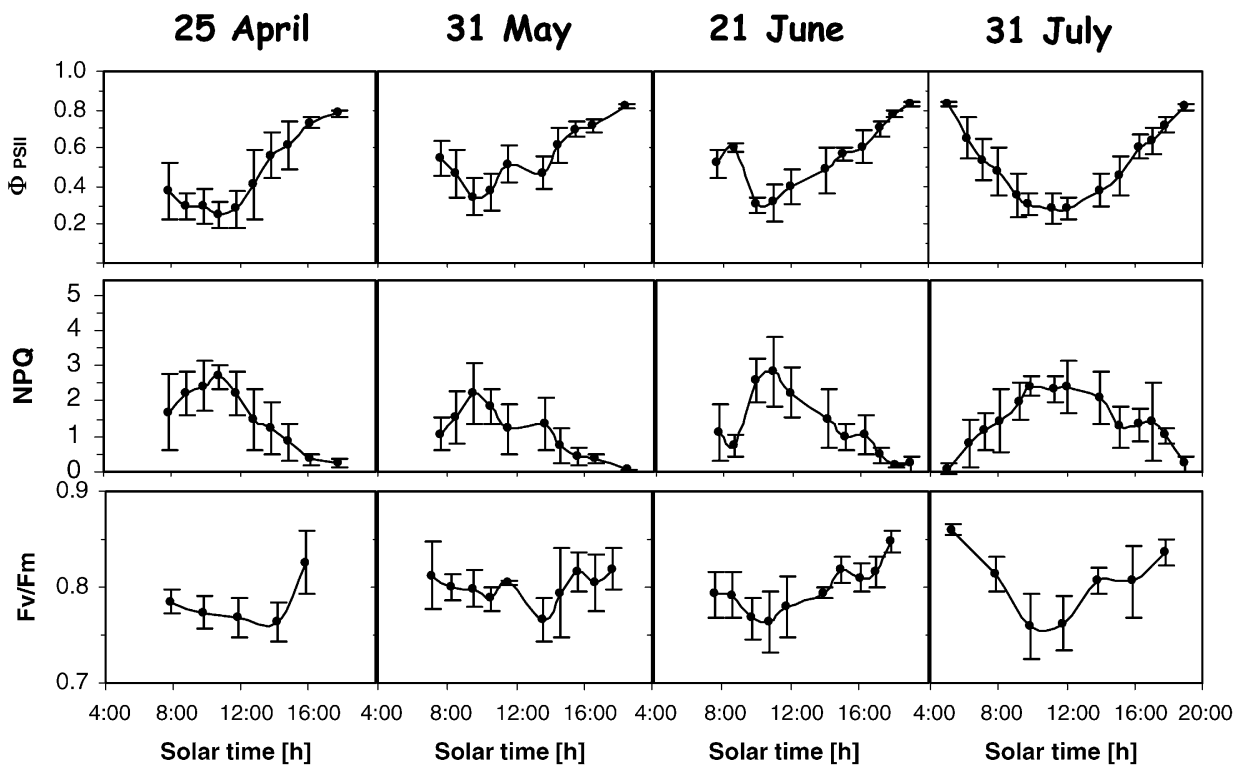

Fig. 5. Diurnal time course of relative quantum efficiency of photosystem II photochemistry ( $\left.\phi_{\text {PSII }}\right)$, non-photochemical quenching coefficient (NPQ) and maximum efficiency of photosystem II photochemistry $\left(F_{\mathrm{v}} / F_{\mathrm{m}}\right)$ of Chamaecytisus proliferus subsp. proliferus var. palmensis measured in leaves on 25 April, 31 May, 21 June and 31 July. Each point represents the mean of nine measurements with their standard deviations.

Table 1

Chlorophyll content (Chl $\left.a+b ; \mathrm{mg} \mathrm{g}^{-1} \mathrm{DW}\right)$, chlorophyll $a: b$ ratio $(\mathrm{Chl} a / b)$ and carotenoid:chlorophyll ratio (Car/Chl) of Chamaecytisus proliferus subsp. proliferus var. palmensis from April to July

\begin{tabular}{lcccc}
\hline & 25 April & 31 May & 21 June & 31 July \\
\hline Chl $a+b$ & $4.9 \pm 0.6^{\mathrm{a}}$ & $6.5 \pm 0.6^{\mathrm{c}}$ & $5.6 \pm 0.4^{\mathrm{a}, \mathrm{b}}$ & $5.9 \pm 0.6^{\mathrm{a}, \mathrm{b}}$ \\
Chl $a / b$ & $3.6 \pm 0.2$ & $3.5 \pm 0.3$ & $3.5 \pm 0.2$ & $3.4 \pm 0.5$ \\
Car/Chl & $0.38 \pm 0.04^{\mathrm{a}}$ & $0.37 \pm 0.02^{\mathrm{a}}$ & $0.44 \pm 0.03^{\mathrm{b}}$ & $0.39 \pm 0.02^{\mathrm{a}, \mathrm{b}}$
\end{tabular}

Each value is a mean \pm S.D., $n=6$. Different letters denote significant differences between days $(P<0.05)$.

significant differences during the drought period (Fig. 5).

Table 1 shows the effects of the drought period on the total chlorophyll content $(\mathrm{Chl} a+b)$, chlorophyll $a: b$ ratio $(\mathrm{Chl} a / b)$ and carotenoid:chlorophyll ratio (Car/Chl). Chl $a+b$ and $\mathrm{Chl} a / b$ did not show significant changes during this period but there was a slight increase in the ratio $\mathrm{Car} / \mathrm{Chl}$.

\section{Discussion}

\subsection{Water relations}

Plant and soil water status showed a gradual decrease during the studied period when drought in- creased. Minimum values of $\Psi(-2.0 \mathrm{MPa})$ were similar to those reached in others woody Mediterranean species in mid-summer (Lo Gullo and Salleo, 1988; Castell et al., 1994) and minimum $\mathrm{RWC}_{\text {leaf }}$ values did not decrease below $70 \%$. These results suggest that tagasaste was subject to mild drought conditions during the studied period (Cornic and Massacci, 1996; Chaves et al., 2002). Furthermore, the increase in VPD with time further enhanced these drought conditions. Both, early morning $\Psi$ and midday $\Psi$ decreased with the time, showing similar diurnal curves of $\Psi$ for the different days.

The pattern of $\Psi$ in response to drought differs amongst species, with two extreme types, i.e. anisohydric and isohydric plants (Stocker, 1956). In both types, the predawn $\Psi$ decreases with the drought, but 
while anisohydric plants show large differences in midday $\Psi$ amongst watering treatments, the isohydric plants do not show appreciable differences in midday $\Psi$ (Tardieu and Simmoneau, 1998). Therefore, tagasaste can be considered an anisohydric plant. This pattern has been shown in sunflower (Tardieu et al., 1996) and in woody species, e.g. almond (Wartinger et al., 1990) and peach (Steinberg et al., 1989), and it is linked to stomatal control. These plants lack a tight stomatal control during dehydration, thus showing a gradual decrease in the $\mathrm{RWC}_{\text {leaf }}$ when exposed to water shortage. In tagasaste, decrease of $\mathrm{RWC}_{\text {leaf }}$ was not much pronounced despite an obvious reduction in $\mathrm{RWC}_{\text {soil }}$. This indicates either a sensitive control of water losses, which is neither evidenced by the observed gas exchange pattern nor by only small changes of leaf water potentials, or efficient abilities for osmoregulation. Which such a strategy, a plant is efficient in productivity also under a prolonged drought.

\subsection{Gas exchange}

Numerous studies of leaf gas exchange in Mediterranean climates have demonstrated similar leaf responses to those described here: decreasing $A$ and $g_{\text {s }}$ from spring to summer with increasing drought (Oechel et al., 1981; Tenhunen et al., 1990). If the main limitation of $A$ were stomatal closure, then we would expect low $g_{\mathrm{s}}$ and, consequently, decreased $C_{\mathrm{i}}$ values. In our study, $C_{\mathrm{i}}$ was calculated using a conventional formula (Farquhar et al., 1978). $C_{\mathrm{i}}$ calculated in this way, decreased rarely in proportion to the decrease of $A$, and $A$ and $g_{\mathrm{s}}$ decreased in parallel. In fact, the magnitude of $C_{\mathrm{i}}$ decrease is often much less than that of the decrease in $A$ (Xu and Shen, 1996). In our study, no significant $C_{\mathrm{i}}$ decrease was observed. It is likely that an increased $\mathrm{CO}_{2}$ efflux from photorespiration, due to an increased leaf temperature (Osmond and Grace, 1995), is responsible for the difference in extent of decline in $A$ and $C_{\mathrm{i}}$. Increased photorespiration is a common response to water stress (Lawlor, 1995), and may be a mechanism to avoid photoinhibitory damage when photosynthesis is reduced by carbon availability (Osmond and Grace, 1995; Kozaki and Takeba, 1996).

In addition, decreases in $g_{\mathrm{s}}$ are not as drastic to reduce substantially leaf carbon gain. Results obtained by Lefroy et al. (2001a) in Australia showed that tagasaste has a root system which enables the plant to access groundwater at depth allowing this plant to maintain relatively high values of $g_{\mathrm{s}}$. The decrease of WUE during the experiment, as a result of the decrease of $A$ and the slight increase of $E$, became accentuated by the atmospheric environmental conditions, mainly VPD since intrinsic water use efficiency, which removes the VPD effect, did not show significant differences during the studied period. As was observed here, Huc et al. (1994) found that $A / g_{\mathrm{s}}$ did not change significantly throughout the year in tropical rain forest tree species. Also with Canarian laurel forest trees that are not much stress affected in their natural habitat no distinct seasonality of the $A / g_{\mathrm{S}}$ ratio could be observed (González-Rodríguez et al., 2001, 2002). By contrast, in some Mediterranean shrubs and trees this parameter increases markedly during the summer (Peñuelas et al., 1998; Flexas et al., 2001). Obviously, tagasaste does not acclimate sufficiently to maintain unchanged high $A$ rates under seasonal water limitations but does not restrict gas exchange to a degree that two-peaked diurnal courses ("midday depression") would be observed. Such a pattern would be accompanied by a stabilization or even improvement of leaf water potential values during the day.

\subsection{Chlorophyll fluorescence}

$\phi_{\text {PSII }}$ showed pronounced diurnal changes that are most probably caused by (zeaxanthin + antheraxanthin)-dependent energy dissipation in the antennae. These changes in PSII apparently represent a regulatory adjustment of PSII to the demand for products of electron transport, and are unlikely to limit photosynthetic productivity (Demmig-Adams and Adams, 1996).

A great decrease of $\phi_{\text {PSII }}$ over the day was shown on all days, but contrary to what was shown by Munné-Bosch et al. (1999) for other Mediterranean evergreen shrubs, the decrease in tagasaste was not enhanced by water stress. The values recovered at the end of the day show a down regulation of photosynthesis and no damage of the photosynthetic function by dehydration (Cornic and Massacci, 1996).

Although $F_{\mathrm{v}} / F_{\mathrm{m}}$ values at midday were slightly lower than those obtained early in the morning and late afternoon, they were always in the range 
considered normal for a healthy non-stressed plant (Bolhár-Nordenkampf and Öquist, 1993). The maintenance of constant $F_{\mathrm{v}} / F_{\mathrm{m}}$ values at midday throughout the study demonstrates the lack of drought induced damage to PSII photochemistry, as has been reported also for many other species (Genty et al., 1987; Jiménez et al., 1999). It is well known the PSII protector role of carotenoids under conditions of excess of light which are enhanced in drought conditions. In our study, we observed a slight increase in the ratio $\mathrm{Car} / \mathrm{Chl}$, which partly explains the absence of drought-induced damage to PSII (Demmig-Adams and Adams, 1996). This parallels the high resistance to photoinhibitory damage exhibited by other Mediterranean species under summer drought (Werner et al., 1999).

We conclude that tagasaste can endure a mild drought, developing a more negative water potential, but closing gradually its stomata as the water stress increases and dissipating the excess light without damage to the photosynthetic apparatus, with a moderate decrease in photosynthetic rates. While this might be considered as a conventional response to drought, this performance is not a general rule. In some cases changes in leaf physiology were more closely linked to changes in the soil water content than to those in leaf water status (Jones, 1985).

In tagasaste, photosynthesis under drought is controlled through stomatal limitation, but $\mathrm{CO}_{2}$ uptake becomes only halved. Even with higher atmospheric demands, transpiration rates remain at moderate levels and leaf water potential recovers more or less at the end of a day. A seasonal decrease of predawn $\Psi$ indicates that leaf water relations are at least somewhat stabilized by osmoregulatory processes. Diurnal variations in gas exchange were less pronounced than those in macchia plants under eu-Mediterranean conditions (e.g. Lösch et al., 1982; Beyschlag et al., 1986), where $\Psi_{\text {midday }}$ reached values nearly twice as low as measured in the present study. This agrees with the milder conditions of a humid Mediterranean climate where tagasaste occurs naturally. It underlines the usefulness of tagasaste as a biomass producing plant under conditions of mild drought. It remains to be proven whether or not this species can endure with sufficient production and vitality eu-Mediterranean conditions with a prolonged severe water shortage.

\section{Acknowledgements}

This research was supported by IFD97-1049-C08-04. We express our gratitude to La Laguna University and Santander Bank for a grant to Alberto Martín Olivera.

\section{References}

Arredondo, S., Aronson, J., Ovalee, C., del Pozo, A., Avendano, J., 1998. Screening multipurpose legume trees in central Chile. Forest Ecol. Manag. 109, 221-229.

Assefa, G., 1998. Biomass yield, botanical fractions and quality of tagasaste, (Chamaecytisus palmensis) as affected by harvesting interval in the highlands of Ethiopia. Agrofor. Syst. 42, 13-23.

Beyschlag, W., Lange, O.L., Tenhunen, J.D., 1986. Photosynthese und Wasserhaushalt der immergrünen mediterranen Hartlaubpflanze Arbutus unedo L. im Jahreslauf am Freilandstandort in Portugal. I. Tagesläufe von $\mathrm{CO}_{2}$-Gaswechsel und Transpiration unter natürlichen Bedingungen. Flora 178, 409-444.

Bilger, W., Schreiber, U., Bock, M., 1995. Determination of the quantum efficiency of photosystem II and of non-photochemical quenching of chlorophyll fluorescence in the field. Oecologia 102, 425-432.

Bolhár-Nordenkampf, H.R., Öquist, G., 1993. Chlorophyll fluorescence as a tool in photosynthesis research. In: Hall, D.O., Scurlock, J.M.O., Bolhár-Nordenkampf, H.R., Leegod, R.C., Long, S.P. (Eds.), Photosynthesis and Production in a Changing Environment: A Field Laboratory Manual. Chapman and Hall, London, pp. 193-206.

Borens, F., Poppi, D.P., 1990. The nutritive and feeding value for ruminants of tagasaste (Chamaecytisus palmensis), a leguminous tree. Anim. Feed Sci. Technol. 28, 275-292.

Castell, C., Terradas, J., Tenhunen, J.D., 1994. Water relations, gas exchange, and growth of resprouts and mature plant shoots of Arbutus unedo L. and Quercus ilex L. Oecologia 98, 201-211.

Chaves, M., Maroco, J.P., Pereira, J.S., 2002. Understanding plant responses to drought-from genes to the whole plant. Funct. Plant Biol. 30, 239-264.

Cornic, G., Massacci, A., 1996. Leaf photosynthesis under drought stress. In: Baker, N.R. (Ed.), Photosynthesis and the Environment. Kluwer Academic Publishers, Dordrecht, pp. 347-366.

Daget, P., 1977. Le bioclimat méditerraneén: Caracteres généraux et modes de caractérisation. Vegetation 34, 1-20.

Demmig-Adams, B., Adams III, W.W., 1996. Xantophyll cycle and light stress in nature: uniform response to excess direct sunlight among higher plant species. Planta 198, 460-470.

Faria, T., Silverio, D., Breia, E., Cabral, R., Abadia, A., Abadia, J., Pereira, J.S., Chaves, M.M., 1998. Differences in the response of carbon assimilation to summer stress (water deficits, high light and temperature) in four Mediterranean tree species. Physiol. Plant 102, 419-428.

Farquhar, G.D., Dubbe, D.R., Raschke, K., 1978. Gain of the feedback loop involving carbon dioxide and stomata. Theory and measurement. Plant Physiol. 62, 406-412. 
Flexas, J., Gulías, J., Jonasson, S., Mus, M., Medrano, H., 2001. Seasonal patterns and control of gas exchange in local populations of the Mediterranean evergreen shrub Pistacia lentiscus L. Acta Oecol. 22, 33-43.

Francisco-Ortega, J., Jackson, M.T., Santos-Guerra, A., Fernández-Galván, M., 1991. Historical aspects of the origin and distribution of tagasaste (Chamaecytisus proliferus (L. fil.) Link ssp. palmensis (Christ) Kunkel), a fodder tree from the Canary islands. J. Adelaide Botanical Garden 14, 67-76.

Francisco-Ortega, J., Newbury, H.J., Ford-Lloyd, B.V., 1993. Numerical analyses of RAPD data highlight the origin of cultivated tagasaste (Chamaecytisus proliferus ssp. palmensis) in the Canary Islands. Theor. Appl. Genet. 87, 264-270.

Genty, B., Briantais, J.M., Viera da Silva, J., 1987. Effects of drought on primary photosynthetic processes of cotton leaves. Plant Physiol. 83, 360-374.

Genty, B., Briantais, J.M., Baker, N.R., 1989. The relationship between the quantum yield of photosynthetic electron transport and quenching of chlorophyll fluorescence. Biochim. Biophys. Acta 990, 87-92.

Gratani, L., Ghia, E., 2002. Adaptive strategy at the leaf level of Arbutus unedo L. cope with Mediterranean climate. Flora 197, 275-284.

González-Rodríguez, A.M., Morales, D., Jiménez, M.S., 2001. Gas exchange characteristics of a Canarian laurel forest tree species (Laurus azorica) in relation to environmental conditions and leaf canopy position. Tree Physiol. 21, 1039-1045.

González-Rodríguez, A.M., Morales, D., Jiménez, M.S., 2002. Leaf gas exchange characteristics of a Canarian laurel forest tree species (Persea indica) in natural conditions. J. Plant Physiol. 159, 695-704.

Huc, R., Ferhi, A., Guehl, J.M., 1994. Pioneer and late stage tropical rainforest tree species (French Guiana) growing under common conditions differ in leaf gas exchange regulation, carbon isotope discrimination and leaf water potential. Oecologia 99, 297-305.

Jiménez, M.S., González-Rodríguez, A.M., Morales, D., 1999. Effect of dehydration on the photosynthetic apparatus of sun and shade leaves of laurel forest trees. Z. Naturf. 55c, 704-710.

Jones, H.G., 1985. Physiological mechanisms involved in the control of leaf water status: implications for the estimation of tree water status. Acta Hort. 171, 714-719.

Kozaki, A., Takeba, G., 1996. Photorespiration protects C3 plants from photooxidation. Nature 384, 557-560.

Lawlor, D.W., 1995. The effects of water deficit on photosynthesis. In: Smirnof, N. (Ed.), Environment and Plant metabolism. Flexibility and Acclimation. BIOS Scientific Publisher, Oxford, pp. 129-160.

Lefroy, E.C., Pate, J.S., Stirzaker, R.J., 2001a. Growth, water use efficiency, and adaptive features of the tree legume tagasaste (Chamaecytisus proliferus Link.) on deep sands in south-western Australia. Aust. J. Agric. Res. 52, 221-234.

Lefroy, E.C., Stirzaker, R.J., Pate, J.S., 2001b. The influence of tagasaste (Chamaecytisus proliferus Link.) trees on the water balance of an alley cropping system on deep sand in south-western Australia. Aust. J. Agric. Res. 52, 235-246.
Lichtenthaler, H.K., 1987. Chlorophylls and carotenoids: pigments of photosynthetic biomembranes. Methods Enzymol. 148, 350382.

Lo Gullo, M.A., Salleo, S., 1988. Different strategies of drought resistance in three Mediterranean sclerophyllous trees growing in the same environmental conditions. New Phytol. 108, 267276.

Lösch, R., Tenhunen, J.D., Pereira, J.S., Lange, O.L., 1982. Diurnal courses of stomatal resistance and transpiration of wild and cultivated Mediterranean perennials at the end of the summer dry season in Portugal. Flora 172, 138-160.

Mäkelä, A., Berninger, F., Hari, P., 1996. Optimal control of gas exchange during drought: theoretical analysis. Ann. Bot. 77, 461-467.

Munné-Bosch, S., Nogués, S., Alegre, L., 1999. Diurnal variations of photosynthesis and dew absorption by leaves in two evergreen shrubs growing in Mediterranean fields conditions. New Phytol. 144, 109-119.

Oechel, W.C., Lawrence, W., Mustafa, J., Martínez, J., 1981. Energy and carbon allocation. In: Miller, P.C. (Ed.), Resource Use by Chaparral and Matorral. Springer, Berlin, pp. 151-183.

Osmond, C.B., Grace, S.C., 1995. Perspectives on photoinhibition in the field: quintessential inefficiencies of the light and dark reactions of photosynthesis. J. Exp. Bot. 46, 1415-1422.

Pereira, J.S., Chaves, M.M., 1993. Plant water deficits in Mediterranean ecosystems. In: Smith, J.A.C., Griffiths, H. (Eds.), Water Deficits. Plant Responses from Cell to Community. Bios Scientific Publishers, Oxford, pp. 237-251.

Pérez de Paz, P.L., del Arco Aguilar, M., Acebes Ginoves, J.R., Wildpret de la Torre, W., 1986. Leguminosas Forrajeras de Canarias. Excmo. Cabildo Insular de Tenerife.

Peñuelas, J., Fililla, I., Llusiá, J., Siscart, D., Piñol, J., 1998. Comparative field study of spring and summer leaf gas exchange and photobiology of the mediterranean trees Quercus ilex and Phyllyrea latifolia. J. Exp. Bot. 49, 229-238.

Steinberg, S.L., McFarland, M.J., Miller, J.C., 1989. Effect of water stress on stomatal conductance and leaf water relations of leaves along current-year branches of peach. Aust. J. Plant Physiol. 16, 549-560.

Stocker, O., 1956. Die Abhängigkeit des Transpiration von den Umweltfaktoren. In: Encyclopedia of Plant Physiology. Springer-Verlag, Berlin, pp. 436-488.

Tardieu, F., Lafarge, T., Simmoneau, T., 1996. Stomatal control by fed or endogenous xylem ABA in sunflower: interpretation of observed correlations between leaf water potential and stomatal conductance in anisohydric species. Plant Cell Environ. 15, 75-84.

Tardieu, F., Simmoneau, T., 1998. Variability among species of stomatal control under fluctuating soil water status and evaporative demand: modelling isohydric and anisohydric behaviors. J. Exp. Bot. 49, 419-432.

Tenhunen, J.D., Catarino, F.M., Lange, O.L., Oechel, W.C., 1987. Plant responses to stress. In: NATO ASI Series, Ecological Sciences, Functional Analysis in Mediterranean Ecosystems, vol. 15. Springer-Verlag, Berlin.

Tenhunen, J.D., Sala Serra, A., Harley, P.C., Dougherty, R.L., Reynolds, J.F., 1990. Factors influencing carbon fixation and 
water use by Mediterranean sclerophyll shrubs during summer drought. Oecologia 82, 381-393.

Tolera, A., Khazaal, K., Orskov, E.R., 1997. Nutritive evaluation of some browse species. Anim. Feed Sci. Technol. 67, 181-185.

Turner, N.C., 1981. Techniques and experimental approaches for the measurement of plant water status. Plant Soil 58, 339-366.

Van Andel, J., Bakker, J.P., Grootjans, A.P., 1993. Mechanisms of vegetation succession: a review of concepts and perspectives. Acta Bot. Neerl. 42, 413-433.

von Caemmerer, S., Farquhar, G.D., 1981. Some relations between the biochemistry of photosynthesis and the gas exchange of leaves. Planta 153, 376-387.
Wartinger, A., Weilmeier, H., Hartung, W., Schultze, E., 1990. Daily and seasonal courses of leaf conductance and abscisic acid in the xylem sap of almond trees (Prunus dulcis M.) under desert conditions. New Phytol. 116, 581587.

Werner, C., Correia, O., Beyschlag, W., 1999. Two different strategies of Mediterranean macchia plants to avoid photoinhibitory damage by excessive radiation levels during summer drought. Acta Oecol. 20, 15-23.

Xu, D.-Q., Shen, Y.K., 1996. Midday depression of photosynthesis. In: Pessarakli, M. (Ed.), Handbook of Photosynthesis. Marcel Dekker Inc., New York, pp. 451-459. 